\title{
KEBERADAAN PERPUSTAKAAN PUSAT UNIVERSITAS PADJAJARAN SELAMA MASA PANDEMI COVID-19
}

\author{
Maula Siti Sarah, Sukaesih, Evi Nursanti Rukmana, Samson CMS \\ Universitas Padjadjaran, Bandung \\ sukaesih@unpad.ac.id
}

\begin{abstract}
ABSTRAK
Artikel ini bertujuan untuk mendeskripsikan peranan serta keberadaan Perpustakaan Pusat Unpad selama masa pandemi COVID-19 untuk memenuhi kebutuhan informasi pemustaka dengan memperhatikan berbagai aspek-aspek penting yang terdapat di dalam sistem perpustakaan. Penelitian ini menggunakan metode deskriptif kualitatif dengan teknik pengambilan data wawancara dan kajian literatur. Data yang digunakan oleh penulis ialah data mengenai sistem layanan perpustakaan serta tantangan yang perlu dihadapi diikuti dengan inovasi sebagai solusi. Hasil penelitian ini merujuk pada sebuah kesimpulan bahwa Perpustakaan Pusat Unpad menghadapi berbagai macam tantangan mulai dari aspek layanan, koleksi, hingga pembagian jam kerja pegawai perpustakaan. Adapun inovasi yang dilakukan oleh pihak Perpustakaan Pusat Unpad untuk dapat tetap melayani pemustaka secara maksimal adalah dengan memberikan Layanan Pustakawan "Subject Specialist" serta melakukan promosi atau pemasaran terkait kegatan, layanan, serta fasilitas perpustakaan melalui sosial media Instagram.
\end{abstract}

Kata kunci: perpustakaan digital, pandemi covid-19, perpustakaan unpad

\section{PENDAHULUAN}

Belakangan dunia dihebohkan dengan kehadiran sebuah virus yang menyebabkan banyaknya manusia berjatuhan, tak sadarkan diri hingga mengantarkan mereka ke kematian. Indikasi utama yang terjadi ialah kesulitas bernafas saat berada di tempat umum. Virus ini bernama SARS-Cov-2 yang menyebabkan penyakit yang dikenal sebagai COVID-19. Pada 11 November 2019, organisasi kesehatan dunia atau WHO mengumumkan ke pada dunia bahwa penyakit COVID-19 ditetapkan sebagai pandemi global. Kasus oenyakit ini pertama kali terjadi di Wuhan, China pada November 2019, lalu menyebar dengan cepat hingga April 2020 ke seluruh dunia. Penyebarannya yang sangat cepat di antara manusia, dengan cara berinteraksi dengan penderita bisa mengantarkan penyakit ini kepada seseorang, menjadikan virus ini sangat berbahaya. Penyebaran virus yang sangat cepat ini membuat masyarakat dunia panik, takut, serta kalut. Hingga hampir sebagian besar pemerintah di berbagai negara memutuskan untuk mengambil tindakan preventif yang diharapkan dapat menekan bahkan menghentikan penyebaran virus ini. Para ahli kesehatan dan tim medis pun juga menghimbau masyarakat untuk melakukan pembatasan baik secara sosial maupun fisikal, dan berdiam di rumah untuk menghindari dan menekan tingkat penyebaran virus ini. 
Di Indonesia, kebijakan lockdown wilayah dilakukan untuk mencegah penyebaran virus ini. Namun, kebijakan ini tidak dilakukan di seluruh wilayah, hanya wilayah-wilayah tertentu saja yang memutuskan untuk menutup aksesibilitas daerah dengan kebijakan lockdown. Salah satu daerah yang melakukan kebijakan ini ialah DKI Jakarta sebagai Ibukota Negara. Kebijakan ini dilakukan secara bertahap dan pada akhirnya, dilakukanlah sebuah pembatasan sosial berskala besar atau yang lebih dikenal sebagai PSBB (Kusnayat, Sumarni, Mansyur, Zaqiah, \& Bandung, 2020). Tujuan dari PSBB ini sendiri ialah untuk membatasi kegiatan serta aktivitas masyarakat dalam suatu wilayah yang diduga terinfeksi COVID-19 dengan cara berkarantina di rumah. Selain kebijakan lockdown dan PSBB, Indonesia juga menerapkan kebijakan Work from Home (WFH) dan School from Home (SFH) yang berarti segala jenis kegiatan pekerjaan dan kegiatan belajar mengajar dilakukan secara daring atau online. Dikutip dari CNN Indonesia dalam Rahman (2020) semenjak pandemi COVID-19 mewabah di Indonesia, setidaknya terdapat 65 perguruan tinggi yang melaksanakan kegiatan belajarmengajar secara daring di rumah masing-masing untuk menvegah penyebaran virus Corona ini (Rahman, 2020). Dalam pelaksanaannya, kegiatan pembelajaran daring ini memungkinkan mahasiswa dan dosen dapat melakukan kegiatan perkuliahan di mana saja, di tempat yang berbeda.

Menurut Moore, Dickson-Deane, dan Galyen (2011) kegiatan pembelajaran online merupakan pembelajaran yang memanfaatkan jaringan internet dengan konektivitas, aksesibilitas, fleksibilitas, dan kemampuan untuk melakukan berbargai jenis interaksi pembelajaran. Penggunaan teknologi serta jaringan internet dapat mengubah cara penyampaian ilmu pengetahuan dan dapat menjadi salah satu cara alternatif pembelajaran yang dilaksanakan di dalam kelas konvensional (Rahman, 2020). Kegiatan pembelajaran secara daring ini tentu memerlukan perangkat-perangkat mobile yang mendukung seperti laptop hingga smartphone untuk mengakses berbagai media pembelajaran seperti Google Classroom, Edmodo, hingga media call conference seperti Google Meet dan Zoom. Kemudahan interaksi pembelajaran yang dapat dilakukan di mana saja hanya dengan memanfaatkan aksesibilitas internet melalui perangkat mobile merupakan salah satu dampak positif dari kegitan pembelajaran daring khususnya dalam kegiatan perkuliahan. Namun, kegiatan pembalajaran daring juga memiliki kekurangannya tersendiri, yaitu: 1) Membutuhkan perangkat (device) yang mendukung; 2) Membutuhkan kuota internet dengan sinyal yang memadai; hingga 3) Terbatasnya akses dalam pencarian informasi. Ketika pandemi COVID-19 mewabah di Indoensia, tentu seluruh lapisan masyarakat dibatasi dalam hal interaksi secara fisik. Hal ini menyebabkan mahasiswa serta civitas akademika lain tidak dapat mengunjungi perpustakaan untuk memenuhi kebutuhan informasinya disebabkan adanya kebijakan pembatasan sosial berskala besar (PSBB). Padahal, dalam kegiatan pembelajaran daring pun, mahasiswa tetap membutuhkan informasi-informasi yang tersedia di perpustakaan. Kebutuhan informasi ini tidak dapat dipenuhi secara maksimal oleh perpustakaan konvensional yang ada di perguruan tinggi selama masa pandemi COVID19.

Rumusan masalah yang terdapat di dalam penelitian ini ialah: 1) Bagaimana sistem pelayanan Perpustakaan Pusat Unpad selama masa pandemic?; 2) Tantangan apa saja yang dihadapi oleh Perpustakaan Pusat Unpad selama masa pandemi COVID-19?; dan 3) Inovasi apa saja yang dilakukan Perpustakaan Pusat Unpad untuk meningkatkan kualitas layanan digitalnya selama masa pandemi COVID-19? Tujuan umum dilakukannya penelitian ini ialah: 
1) Untuk mengetahui bagaimana sistem pelayanan Perpustakaan Pusat Unpad selama masa pandemi COVID-19; 2) Untuk mengetahui tantangan apa saja yang dihadapi Perpustakaan Pusat Unpad selama masa pandemi COVID-19; dan 3) Untuk mengetahui inovasi apa yang dilakukan oleh Perpustakaan Pusat Unpad untuk meningkatkan kualitas layanan digitalnya selama masa pandemi COVID-19, sedangkan tujuan khusus dilakukannya penelitian ini ialah untuk memenuhi tugas Ujian Tengah Semester 3 Mata Kuliah Jasa Layanan Informasi dan Perpustakaan.

\section{TINJAUAN PUSTAKA}

Menurut Kuhltau dalam Tjiptasari (2017) kebutuhan informasi dapat terjadi sebab adanya ketimpangan dalam diri seseorang, yaitu antara pengetahuan yang dibutuhkan dan pengetahuan yang dimiliki (Tjiptasari \& Ridwan, 2017). Menurut Wilson, kebutuhan informasi ialah situasi nyata di mana terdapat hubungan terkait yangtak dapat dipisahkan antara informasi dan kebutuhan. Informasi terbentuk dan dihasilkan karena terdapat kebutuhan atau kepentingan. Di sisi lain, The Library Association mendefinisikan kebutuhan informasi sebagai kemampuan seseorang dalam mengetahui bahwa dirinya belum memiliki pengetahuan yang cukup akan informasi tentang suatu subjek (Tjiptasari \& Ridwan, 2017). Perpustakaan sebagai lembaga informasi yang bertugas untuk menghimpun, mengelola, hingga memberikan layanan jasa informasi perlu memperhatikan aspek kebutuhan informasi pemustaka khususnya bagi perpustakaan perguruan tinggi di masa pandemi ini. Sebab dalam memenuhi kebutuhan akan informasi, umumnya masyarakat akan mendatangi sumber-sumber informasi salah satunya adalah perpustakaan. Setiap perguruan tinggi, perlu memiliki perpustakaan guna memfasilitasi mahasiswa sebagai civitas akademika dalam kegiatan pembelajaran. Hal ini didasari oleh Undang-Undang No. 2 Tahun 1989 tentang Sistem Pendidikan Nasional pada pasal 55 yang menyebutkan bahwa salah satu syarat untuk menyelenggarakan perguruan tinggi harus memiliki perpustakaan.

Perpustakaan perguruan tinggi pada dasarnya berfungsi untuk membantu instasi agar mampu mencapai visi misinya yaitu Tri Dharma Perguruan Tinggi yaitu pendidikan, pengajaran, penelitian, serta pengabdian kepada masyarakat. Menurut Trimo (1985) dalam Effendi, perpustakaan perguruan tinggi memiliki peran penting di antaranya ialah: 1) Memberikan bimbingan kepada mahasiswa untuk memperluas dan meningkatkan minat serta kebutuhan dalam membaca; 2) Membantu mahasiswa dalam kegiatan belajar seperti melenyelsaikan laporan dan lainnya; 3) Mengajarkan mahasiswa dalam pemanfaatan bahan pustaka serta fasilitas lain yang dimiliki oleh perpustakaan; 4) Memberi bantuan kepada staf pengajar dalam menyelesaikan permasalahan dalam bidang pengajaran dan merencanakan kurikulum; 5) Membantu program perkembangan dan pelatihan staf pengajar ; serta 6) Memberikan pelayanan jasa kepada masyarakat sebagai upaya penyebarluasan informasi. Pada umumnya perpustakaan perguruan tinggi memiliki fungsi sebagai berikut: 1) Fungsi edukasi; 2) Fungsi informasi; 3) Fungsi riset; 4) Fungsi rekreasi; 5) Fungsi publikasi; 6) Fungsi deposit; 7) Fungsi interpretasi. Adapun tujuan perpustakaan perguruan tinggi menurut Sulistyo Basuki yaitu: 1) Memenuhi keperluan informasi masyarakat perguruan tinggi yang mencakup staf pengajar, mahasiswa, dan tenaga administrasi perguruan tinggi; 2) Menyediakan bahan pustaka referensi pada semua lapisan akademis; 3) Menyediakan ruang untuk belajar bagi pemustaka; 4) Menyediakan jasa peminjaman yang tepat guna bagi berbagai jenis pemakai; 5) 
Menyediakan jasa informasi kepada lingkungan perguruan tinggi dan juga lembaga industri lokal secara aktif. Perpustakaan sebagai salah satu lembaga informasi tentu memiliki kegiatan layanan yang dapat dimanfaatkan oleh pemustaka. Begitu pun dengan jenis perpustakaan perguruan tinggi. Adapun jenis layanan perpustakaan pada umumnya ialah: 1) Layanan pembaca; 2) Layanan peminjaman; 3) Layanan referensi.

Dalam pelakasanaannya, jenis layanan yang tersedia ini dapat dilakukan dengan dua macam sistem yaitu sistem layanan terbuka dan sistem layanan tertutup. Pada sistem layanan terbuka, pengunjung perpustakaan atau pemustaka dapat membuka-buka bahan pustaka, masuk ke ruang penyimpanan koleksi, dan dapat mengambil bahan pustaka untuk dibaca di tempat bahkan untuk dipinjam pulang. Sementara itu, sistem layanan tertutup ialah sistem layanan yang pemustakanya tidak diperbolehkan memasuki ke ruangan koleksi. Sehingga, pemustaka yang membutuhkan bahan pustaka dapat meilhatnya di daftar katalog dan meminta tolog kepada pustakawan untuk mengambilkannya (Berawi, 2012). Salah satu unsur yang sangat penting bagi setiap perpustakaan perguruan penting ialah bahan pustaka yang menjadi koleksi perpustakaan. Menurut Yusup (1995) bahan psuataka perpustakaan mencakup: 1) Buku teks; 2) Buku referensi; 3) Bahan media cetak bukan buku; dan 4) Bahan media elektronik (Berawi, 2012).

Di Universitas Padjadjaran, Perpustakaan Pusat atau kini disebut juga sebagai Pusat Pengelolaan Pengetahuan Unpad merupakan lembaga informasi yang bertugas untuk memenuhi setiap kebutuhan mahasiswa, staf pengajar, dan civitas akademika lain akan informasi yang dibutuhkannya. Koleksinya sendiri saat awal berdiri terdiri atas buku, jurnal, serta brosur-brosur yang jumlahnya lebih kurang 500 eksemplar, dengan koleksi yang terus berkembang seiring berjalannya waktu, Perpustakaan Pusat Unpad menjadi salah satu lembaga informasi yang sangat dimanfaatkan oleh para mahsiswa Unpad sendiri, namun, adanya pandemi COVID-19 yang terjadi mulai dari akhir tahun 2019 hingga kini, tampaknya para civitas akademika tidak dapat memanfaatkan Perpustakaan Pusat Unpad sebagaimana mestinya. Perlu inovasi serta upaya yang lebih besar agar perpustakaan dapat tetap memenuhi kebutuhan informasi dan dapat dimaanfaatkan secara maksimal oleh para pemustakanya. Keberadaan teknologi yang semakin canggih merupakan salah satu hal yang dapat dimanfaatkan oleh perpustakaan untuk mengembangkan jangkauan dan kualitasnya.

Kemajuan teknologi sangat berpengaruh terhadap peranan serta paradigma perpustakaan itu sendiri, mulai dari bentuk, jenis layanan, hingga jenis koleksi. Ketika mahasiswa dan staf pengajar tidak dapat mengakses perpustakaan konvensional, di sinilah peranan dan keberadaan perpustakaan digital dapat dimanfaatkan secara maksimal untuk menggantikan sementara peran perpustakaan konvensional selama masa pandemi COVID-19. Konsep perpustakaan digital sebenarnya telah lahir pada awal tahun 1940-an dengan Vannenar Bush sebagai penggagasnya. Namun, perpustakaan secara aktif melakukan otomasi fungsifungsi perpustakaan pada tahun 80-an (Supriyanto, n.d.). Menurut IFLA (The International Federation of Library Associations and Instituions) mengartikan perpustakaan digital sebagai perpustakaan yang dikembangkan dan dikelola sesuai dengan prinsip secara internasional yang memiliki objek digital berkualitas sebagai bahan koleksinya (Suharso, Arifiyana, \& Wasdiana, 2020). Di sisi lain, Zainal A. Hasibuan (2005) berpendapat bahwa perpustakaan digital merupakan konsep manajemen perpustakaan yang memanfaatkan keberadaan internet serta teknologi informasi, sementara itu, Ismail Fahmi (2004) menyatakan bahwa perpustakaan 
digital adalah sebuah sistem yang mencakup perangkat elektronik, koleksi digital, mekanisme kerja, serta layanan yang menggunakan berbagai jenis teknologi informasi (Dana, Samosir, \& Widiyasa, 2008). Dari ketiga pendapat tersebut dapat disimpulkan bahwa perpustakaan digital pada dasarnya ialah sebuah perpustakaan yang memanfaatkan keberadaan internet dan teknologi dalam manajemen atau mekanisme kerjanya. Di dalam perpustakaan digital pun terdapat berbagai jenis koleksi digital atau elektronik sebagai bahan pustakanya. Menurut Deegan (2002) perpustakaan digital dapat dilihat dari dua perspektif, yaitu: 1) Perspektif penelitian di mana perpustakaan digital merupakan informasi yang dikumpulkan dan diorganisasikan demi kepentingan pemustaka, dan 2) Perspektif perpustakaan, di mana perpustakaan digital dilihat sebagai sebuah insitusi yang memberikan pelayanan informasi secara digital (Maksum, Buldansyah, \& Prawati, 2008).

Pada dasarnya, pengembangan perpustakaan digital perlu dilakukan secara sistematis dengan formulasi yang terencana. Sebab, perpustakaan digital umumnya merupakan hasil transformasi dari sistem perpustakaan konvensional yang bersifat manual dan analog ke sistem otomatisasi dengan perangkat digital. Di beberapa sisi perpustakaan digital tentu memiliki sisi unggul dibandingkan dengan perpustakaan konvensional. Berikut adalah beberapa kelebihan perpustakaan digital, yaitu: 1) Menghemat ruang, perpustakaan digital memiliki koleksi bahan pustaka yang berbentu virtual sehingga bahan-bahan ini tidak memerlukan sebuah ruangan nyata untuk menyimpannya. Sehingga perpustakaan digital dinilai lebih efisien; 2) Akses ganda, koleksi virtual yang berada di perpustakaan digital diakses dengan jaringan internet secara online, sehingga dapat diakses secara bersamaan dengan lebih dari satu pemustaka; 3) Tidak terikat dengan ruang dan waktu, sebab perpustakaan digital dapat diakses kapan saja dan di mana saja selama perangkat pemustaka dapat terhubung ke akses internet; 4) Koleksi berbentuk multi-media. Koleksi perpustakaan digital pada umumnya ialah koleksi visual, audio, bahkan audio-visual; 5) Biaya lebih murah.

Dalam pembuatan dan berlangganan e-book biayanya cukup mahal, namun dalam hal perawatan, koleksi perpustakaan digital tak memakan biaya yang banyak. Sehingga perpustakaan digital dianggap lebih murah dalam biayanya. Dengan segala kelebihan tersebut dan tersedianya bantuan dari teknologi informasi, perpustakaan digital teteap memerlukan bantuan sumber saya manusia (puStakawan) untuk mengatur mekanisme kerja perpustakaan digital, koleksi digital, serta memberikan pelayanan kepada pemustaka. Krik Hasting (1996) menyebutkan beberapa kriteria pustakawan digital yaitu: 1) Mereka harus membaca secara terus-menerus dan melakukan eksperimen tanpa akhir tetapi selektif dalam pemilihan koleksi perpustakaan; 2) Mereka harus mampu belajar secara mandiri, mencintai kegiatan belajar, dan berani mengambil resiko; serta 3) Mereka harus kemampuan terhadap penggunaan teknologi baik secara potensinya maupun kesulitannya (Supriyanto, n.d.). Seluruh kriteria tersebut harus dimiliki oleh pustakawan digital terutama oleh pustakawan digital perpustakaan perguruan tinggi. Sebab, perpustakaan digital perguruan tinggi akan dimanfaatkan oleh mahasiwa serta civitas akademika lainnya untuk memenuhi kebutuhan informasinya terutama di saat masa pandemi ini di mana akses terhadap perpustakaan konvensional sangat terbatas. Atas dasar hal tersebut, penulis ingin meneliti peran perpustakaan digital Unpad selama masa pandemi ini. 


\section{METODE PENELITIAN}

Tipe penelitian ini ialah tipe deskriptif kualitatif. Di mana penelitian ini bermaksud untuk menkaji lebih dalam keberadaan Perpustakaan Unpad selama masa pandemi COVID-19 bagi mahasiswa serta civitas akademika lainnya. Istilah penelitian kualitatif pada awalnya berasal dari pertentangan pengamatan kualitatif dengan pengamatan kuantitatif. Menurut Krik dan Miller metode kualitatif ialah sebuah tradisi yang bergantung pada pengamatan manusia secara fundamental dalam berhubungan dengan orang-orang tersebut dalam bahasanya dan peristilahannya (Rahmat, 2009). Sementara itu, Bogdan dan Taylor (1975) dalam Berlian menyatakan bahwa penelitian kualitatif ialah penelitian yang menghasilkan data dengan katakata baik secara tertulis maupun secara lisan dari orang-orang yang diamati secara deskriptif dan dilakukan dengan pendekatan pada latar individu secara holistik. Di sisi lain, Denzim dan Lincoln (1987) masih dalam sumber yang sama menyebutkan bahwa penelitian kualitatif ialah penelitian yang menafsirkan sebuah fenomena yang terjadi dengan menggunakan latar ilmiah serta berbagai metode yang ada (Barlian, 2016). Dari beberapa pendapat tersebut, dapat ditarik kesimpulan bahwa penelitian kualitatif ialah penelitian yang mengkaji sebuah fenomena dari sekumpulan orang dengan menggunakan berbagai metode serta menghasilkan hasil yang deskriptif. Pada penelitian kualitatif tidak digunakan prosedur analisis statistik atau cara kuantifikasi lainnya. Selain itu, dibandingkan dengan penelitian kuantitatif, penelitian kualitatif cenderung menekankan kepada ruang lingkup yang mendalam sesuai dengan holistiknya namun terbatas. Sehingga, penelitian kualititaif menghasilkan kesimpulan yang hanya berlaku pada objek studi yang diamati, tidak secara umum. Secara umum, penelitian kualitatif dapat digunakan untuk penelitian tentang kehidupan masyarakat, tingkah laku, sejarah, aktivitas sosial, dan lain-lain. Dengan penelitian kualitatif, para peneliti mampu menemukan serta mengerti apa yang terjadi di dalam sebuah fenomena yang kerap kali sulit untuk dipahami.

Dalam penelitian ini, penulis melakukan wawancara sebagai teknik untuk pengumpulan data. Wawancara yang dilakukan adalah wawancara virtual, di mana penulis mewawancarai subjek yang ingin diteliti melalui aplikasi WhatsApp secara online dan dilakukan pada Senin, 16 November 2020. Menurut Sutrisnohadi (1986) dalam Barlian, ada beberapa hal yang perlu diperhatikan sebelum melakukan interview atau wawancara, yakni: 1) Pastikan bahwa informan atau narasumber ialah orang yang paling memahami mengenai objek yang akan diteliti; 2) Apa yang dinyatakan oleh subjek atau narasumber kepada peneliti merupakan hal yang benar dan dapat dipercaya; 3) Pastikan bahwa interpretasi subjek atau narasumber adalah sama dengan interpretasi peneliti mengenai pertanyaan-pertanyaan yang diajukan (Barlian, 2016).

Menurut Patton (1980) terdapat berbagai macam jenis cara wawancara yaitu: 1) Wawancara pembicaraan informal, di mana pada hal ini biasanya hubungan antara pewawancara dengan subjek yang akan diwawancarai dalam suasana yang biasa saja atau wajar. Pembicaraan dalam wawancara tipe ini mengalir seperti obrolan sehari-hari sehingga narasumbertidak menyadari bahwa ia sedang melakukan wawancara; 2) Pendekatan dengan petunjuk umum wawancara, dan 3) Wawancara baku serta terbuka (Barlian, 2016). Selain wawancara, penelitian ini juga menggunakan kajian literatur sebagai pendukung di dalam ruang lingkup penelitian secara teoritis. Menurut Frankael, Wallen, \& Hyun (2012) kajian literatur ialah suatu kajian yang mendukung masalah tertentu di dalam topik penelitian yang sedang dikerjakan (Yusuf \& Khasanah, 2009). Sebuah kajian pustaka dapat mencakup 
ringkasan serta uraian mengenai topik tertentu secara lengkap dan mutakhir, sebagaimana yang ditemukan dalam artikel jurnal dan buku ilmiah. Di dalam sebuah penelitian kualitatif, tentu terdapat subjek penelitian di mana subjek ini biasa juga disebut sebagai informan yang memberikan informasi serta-data-data yang berkaitan dengan topik yang diangkat oleh peneliti.

Adapun subjek penelitian ini adalah Sri Rakhmiyati, S.Sos., M.Ikom sebagai Koordinator Unit Perpustakaan Pusat Unpad. Sementara itu, yang menjadi objek dalam penelitian ini adalah layanan Perpustakaan Pusat Unpad. Peneliti melakukan observasi terhadap sistem layanan Perpustakaan Pusat Unpad selama masa pandemi COVID-19 berlangsung. Perpustakaan Pusat Unpad saat ini merupakan unit yang dinaungi oleh Direktorat Sumber Daya Akademik dan Perpustakaan yang dipimpin oleh seorang Direktur serta dibantu dengan Sekretaris Direktorat yang bertugas untuk memberikan pelayanan koleksi pustaka serta informasi demi keperluan penelitian, pendidikan dan pengajaran, serta pengabdian masyarakat.

\section{HASIL DAN PEMBAHASAN}

Semenjak pandemi COVID-19 mulai mewabah di Indonesia, Perpustakaan Pusat Unpad tentu melakukan sebuah kebijakan preventif sebagaimana fasilitas umum lainnya. Di dalam hal ini, yang menjadi sangat penting dan utama ialah sistem pelayanan perpustakaan yang sebelumnya dilakukan secara tatap muka diubah mekanisme kerjanya disesuaikan dengan kondisi yang ada. Sebab tidak mungkin Perpustakaan Pusat Unpad memaksakan untuk tetap menyediakan jasa pelayanan seperti biasanya. Dalam pelaksanaan pelayanan, Perpustakaan Pusat Unpad mengambil kebijakan untuk tidak mengizinkan mahasiswa maupun civitas akademika lain untuk beraktifitas di sekitar lingkungan Perpustakaan Pusat Unpad termasuk menggunakan layanan serta fasilitas perpustakaan demi menghindari penyebaran wabah penyakit COVID-19 yang makin hari semakin meningkat jumlahnya. Sebenarnya, mahasiswa masih dapat menggunakan layanan yang bersifat administratif seperti pembuatan surat bebas perpustakaan atau penyerahan tesis serta disertasi. Namun, sebisa mungkin mahasiswa yang akan menggunakan layanan ini diharapkan untuk melakukannya secara daring (online) dengan menghubungi ke alamat email Perpustakaan Pusat Unpad untuk mencegah adanya kontak langsung antara pemustaka dengan pustakawan. Perubahan yang terjadi pada mekanisme pelayanan serta sistem kerja secara umum di Perpustakaan Pusat Unpad tentu memberikan dampak yang signifikan. Berbagai tantangan baru mulai bermunculan seiringnya dengan perubahan sistem yang ada. Tantangan tersebut hadir dari berbagai macam aspek seperti aspek layanan, aspek pengunjung, aspek koleksi, sistem kerja, hingga kegiatan lainnya. Seperti yang sempat disinggung sebelumnya, dalam hal pelayanan Perpustakaan Pusat Unpad tidak bisa melayanani pemustaka secara langsung.

Tantangan lain yang dihadapi oleh Perpustakaan Pusat Unpad selain dalam aspek layanan ialah dalam aspek ketersediaan koleksi. Koleksi yang dimiliki Perpustakaan Pusat Unpad sebagian besar tersedia dalam bentu fisik serta e-book yang tersedia pun tidak ada yang berbahasa Indonesia dengan jumlah yang terbatas. Hal ini tentu akan sangat mempengaruhi kualitas layanan digital Perpustakaan Pusat Unpad. Koleksi digital di perpustakaan pada umumnya menyangkut e-journal, e-book, e-zines, serta bahan pustaka lainnya yang tersedia dalam bentuk elektronik. Baik bahan pustaka yang terlahir dalam bentuk analog kemudian mengalami proses digitalisasi, maupun bahan pustaka yang terlahir dalam bentuk digital.

Selain dalam aspek koleksi, Perpustakaan Pusat Unpad juga mengalami tantangan dalam 
pembagian sistem kerja. Selama masa pandemi COVID-19, Perpustakaan Pusat Unpad tidak menerima kunjungan pemustaka sehingga tidak ada kegiatan serta aktifitas yang terjadi di gedung perpustakaan secara fisik. Hal ini mempengaruhi ke dalam pembagian sistem kerja pegawai yang mengalami penyusunan kembali menyesuaikan dengan situasi yang ada, di mana saat ini pegawai bekerja 2 hari dalam satu minggu dengan pembagian jadwal: Senin-Rabu dan Selasa-Kamis, sedangkan untuk hari Jum'at pegawai bekerja secara daring melalui aplikasi call conference seperi Zoom, Goggle Meet, dan lainnya dari rumah. Dengan berbagai tantangan yang ada, Perpustakaan Pusat Unpad perlu melakukan berbagai inovasi sebagai solusi dari permasalahan yang muncul. Inovasi ini perlu dipikirkan secara matang dan berorientasi pada kepentingan mahasiswa serta civitas akademika sebagai pemustakanya. Sehingga, Perpustakaan Pusat Unpad dapat terus eksis serta terus dimanfaatkan secara maksimal oleh pemustakanya. Inovasi yang dapat dilakukan oleh Perpustakaan Pusat Unpad dalam hal pelayanan ialah dengan memanfaatkan keberadaan perpustakaan digital berbasis website. Dalam hal ini, Unpad memiliki beberapa website yang berisi berbagai bahan pustaka yang dapat diakses oleh para mahasiswa dan civitas akademika lainnya. Berikut ialah website yang dikelola oleh pihak Perpustakaan Pusat Unpad yaitu: 1) https://ibrary.unpad.ac.id di mana website ini dapat digunakan pemustaka yang memerlukan bahan rujukan atau referensi serta informasi lainnya; 2) https://repository.unpad.ac.id yang menyediakan gray literatur; 3) https://kandaga.unpad.ac.id yang dapat diakses oleh pemustaka; dan 4) https:/jurnal.unpad.ac.id yang menyediakan berbagai judul artikel ilmiah.

Berbagai macam website yang dimiliki dan dikelola oleh Perpustakaan Pusat Unpad, tersedia pula berbagai macam jenis layanan yang dapat digunakan oleh pemustaka selama masa pandemi COVID-19 ini, yaitu: 1) Layanan adminisitratif, jika mahasiswa serta civitas akademika lain ingin membuat surat. Layanan ini dilakukan secara daring, sehingga pemustaka yang ingin menggunakan layanan administratif ini dapat mengirimkan email ke alamat perpustakaan@unpad.ac.id; 2) Layanan penelusuran informasi dengan penggunaan OPAC (Online Public Access Catalogue) sebagai alat bantu serta ketersediaan pustakawan subject specialist yang akan membantu pemustaka dalam penelusuran informasi, bahan rujukan, dan lainnya; 3) Pengembalian buku yang dilakukan dengan cara mengirimkan buku yang dipinjam pemustaka melalui jasa kurir atau paket dengan catatan selama Perpustakaan Pusat Unpad tidak menyediakan layanan secara tatap muka, pemustaka yang telat mengembalikan buku tidak dikenakan sanksi atau denda keterlambatan. 


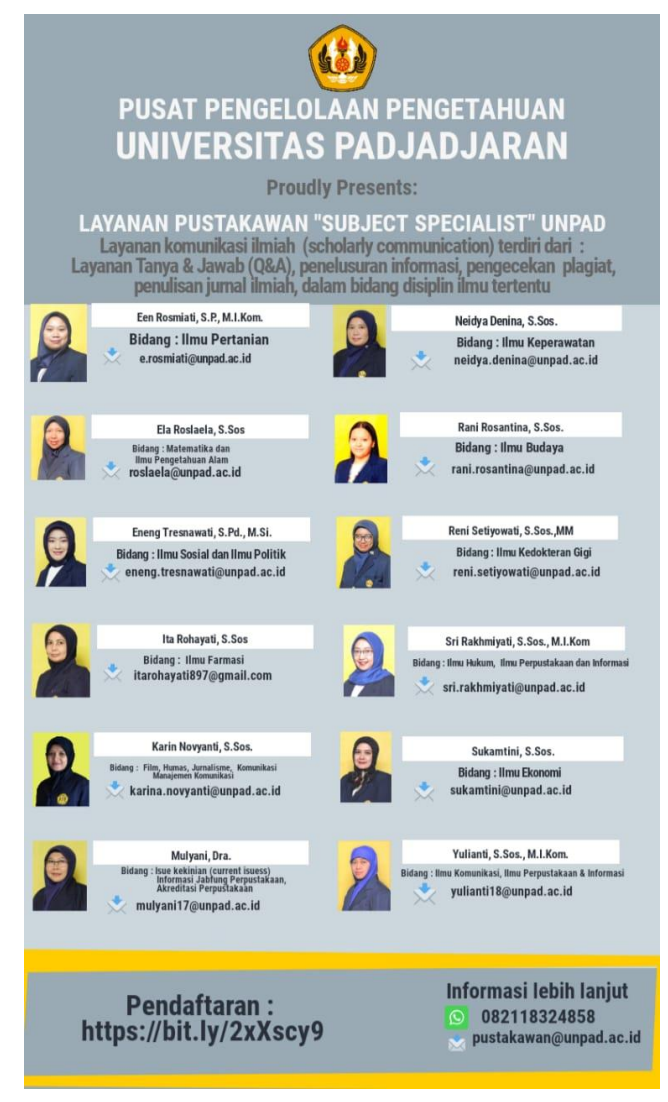

Gambar 1. Layanan Pustakawan "Subject Specialist" Perpustakaan Pusat Unpad

Sumber: Perpustakaan Pusat-Pusat Pengelolaan Pengetahuan Unpad, 2020

Apabila sekiranya pemustaka membutuhkan informasi dan ingin berkomunikasi dengan para pegawai Perpustakaan Pusat Unpad, pemustaka dapat langsung menghubungi kontak yang telah tersedia serta bisa langsung berhubungan dengan pegawai sesuai dengan kaidah keilmuan masing-masing. Layanan ini mencakup layanan tanya jawab, layanan penelusuran informasi, pengecekan plagiarisme, dan sebagainya. Dengan tersedianya layanan ini, Perpustakaan Pusat Unpad ingin tetap membangun koneksi serta hubungan antara pustakawan serta pemustaka, meskipun koneksi yang dibangun hanya dapat dilakukan melalui sosial media. Hubungan yang terjadi antara pustakawan dengan pemustaka di dalam sebuah layanan dapat dikategorikan sebagai sebuah proses komunikasi interpersonal. Di mana dalam proses komunikasi ini, pustakawan berusaha untuk membantu pemustaka dalam memberikan pemhaman informasi dan memberikan pemahaman tentang apa yang sebenarnya pemustaka butuhkan. Menurut Martini (2009) dalam Ananda, ada beberapa tahapan yang terjadi dalam hubungan interpersonal yaitu: 1) Intiating, di mana seseorang mengenal orang lain; 2) Experimenting; 3) Intensifying, ketika komunikasi yang terjalin cukup intens; 4) Integrating; 5) Bonding, di mana hubungan yang terjalin sudah masuk ke tahap formal dan diakui oleh pihak ketiga; 6) Differentiating; 7) Circumscribing, di mana komunikasi yang terjalin mulai terbatas; 8) Stagnating, di mana komunikasi yang terjalin sudah terhenti; 9) Avoiding; dan 10) Terminating, di mana hubungan yang terjalin terputus (Ananda \& Nelisa, 2013).

Dalam hal penyediaan koleksi, Perpustakaan Pusat Unpad menggunakan fasilitas sistem SSO EZProxy yang kemudian dihubungkan dengan sistem PAUS Unpad (https://pintu.unpad.ac.id). 


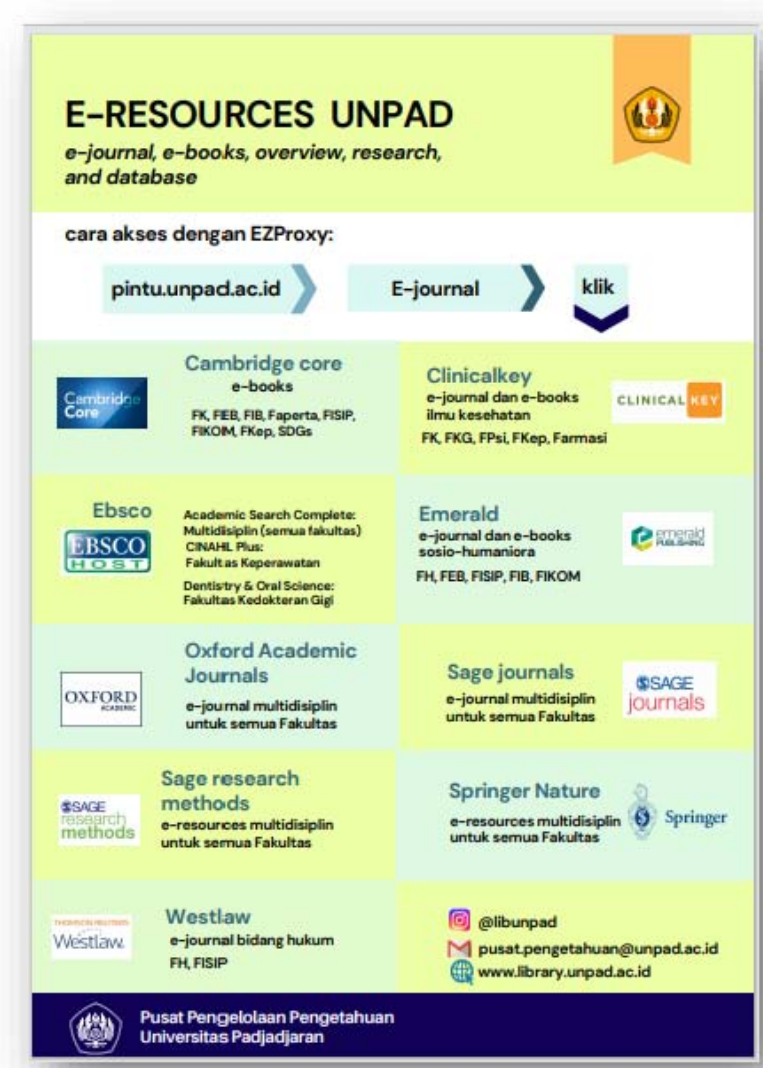

Gambar 2. E-Resources Unpad

Sumber: Perpustakaan Pusat-Pusat Pengelolaan Pengetahuan Unpad, 2020

Fasilitas SSO (Single Sing On) memungkinkan pemustaka dapat mengakses e-journal serta e-books yang dilanggan. Menurut Priyo Puji Nugroho (2012) dalam Aini, SSO merupakan sebuah sistem yang membuat user hanya perlu mengingat satu username serta password untuk memakses berbagai layanan sekaligus (Aini, Rahardja, \& Naufal, 2018). Dengan menerapkan sistem SSO, user atau dalam hal ini pemustaka hanya perlu melakukan satu kali login saja untuk mengakses berbagai layanan sekaligus. Sehingga, terhindarnya kejadian login ganda oleh user atau pemustaka. Sebenarnya, sistem SSO ini tidak jauh berbeda dengan sitem website pada umumnya, tetapi sistem SSO sebagian besar bertugas untuk melakukan authenfikasi terhadap user. Adapun EZProxy dapat didefinisikan sebagai sebuah script yang membuat user solah-olah berada di jaringan internet sebuah kampus. Dengan menggunakan fasilitas sistem SSO EZProxy yang dihubungkan dengan sistem PAUS Unpad, pemustaka dapat mengakses berbagai jurnal yang telah dilanggan perpustakaan secara bebas dan gratis. Adapun koleksi bahan pustaka (e-books dan e-journals) tersebut ialah: 1) Cambridge, yang berisi e-books multidisplin; 2) Clinicalkey, yang berisi e-books serta ejournals ilmu kesehatan; 3) Ebsco, yang berisi bahan pustaka multidisiplin; 4) Emerald, yang berisi bahan pustaka dengan ilmu sosial; 5) Oxford, yang berisi bahan pustaka multidisplin; 6) Sage Journal, yang berisi e-journal multidisiplin; 7) Sage Research Methods, yang berisi bahan pustaka metodologi penelitian dari berbagai disiplin ilmu; 8) Spinger Nature, yang berisi bahan pustaka dari berbagai displin ilmu; dan 9) Westlaw, berisi bahan pustaka yang berhubunugan dengan ilmu hukum. Semua bahan pustaka tersebut dapat diakses oleh para pemustaka dengan masuk ke dalam sistem PAUS Unpad. 
Untuk memperluas dan menambah jumlah koleksi yang telah ada, perpustakaan sebagai lembaga informasi dapat melakukan kerjasama dengan berbagai lembaga informasi lain untuk saling membantu melengkapi koleksi perpustakaan agar semakin lengkap. Menurut Purwono (2009) dalam Mutia, kerjasama perpustakaan adalah kegiatan kerjasama yang melibatkan dua perpustakaan atau lebih. Hal ini terjadi sebab setiap perpustakaan tidak mampu berdiri sendiri dalam memnuhi kebutuhan informasi pemustakanya. Sementara itu, menurut Sulistyo Basuki, kerjasama perpustakaan ini timbul karena banyaknya pertumbuhan bahan pustaka selama satu abad terakhir ini terutama buku dan majalah (Mutia, 2017). Begitu pun dengan Perpustakaan Pusat Unpad, saat ini Perpustakaan Pusat Unpad telah melakukan kerja sama dengan Perpustakaan Nasional, dan dalam progress dengan Dinas Perpustakaan dan Arsip Daerah (Dispusipda) Jawa Barat. Dengan terjalinnya kerjasama ini, artinya ada beban serta tanggung jawab yang dipikul secara bersama-sama oleh pihak-pihak yang bersangkutan. Menurut Mutia (2017) ada alasan mengapa kerjasama perpustakaan menjadi penting yaitu: 1) Pertumbuhan bahan pustaka yang sangat cepat seperti buku, majalah, dll; 2) Pertumbuhan ilmu pengetahuan; 3) Adanya kesadaran akan perlunya kerjasama secara internasional; 4) Melebarnya kesempatan pendidikan ke seluruh dunia; 5) Adanya kemajuan teknologi komunikasi dan informasi yang memungkinkan terjalinnya kerjasama secara cepat; dan 6) Adanya tuntutan untuk memperoleh informasi secara cepat dan akurat dari pemustaka (Mutia, 2017).

Selain kerjasama, hal lain yang penting untuk dilakukan oleh pihak perpustakaan untuk tetap eksis di kalangan pemustakanya ialah dengan melakukan promosi perpustakaan. Menurut Yenianti, promosi merupakan salah satu kegiatan dari layanan perpustakaan yang bertugas untuk mengkomunikasikan sumber-sumber belajar seluruh anggota perpustakaan, baik koleksi non-digital maupun koleksi digital (Yenianti, 2019). Sementara itu, Darmono menyebutkan bahwa promosi merupakan mekanisme pemasaran yang komunikatif dengan memanfaatkan teknik hubungan masyarakat secara persuasif (Yenianti, 2019). Salah satu sarana yang dapat dimanfaatkan untuk melakukan promosi ialah sosial media. Bagi perpustakaan perguruan tinggi, sebagian besar pemustaka mereka berasal dari kalangan mahasiswa. Di mana kini, hampir sebagian besar mahasiswa pasti memiliki sosial media untuk berkomunikasi. Salah satu sosial media yang cukup digandrungi ialah Instagram. Perpustakaan Pusat Unpad melakukan umumnya melakukan kegiatan pemasaran di akun official Instagram yaitu @libunpad. Di sana, Perpustakaan Pusat Unpad mengkomunikasikan berbagai kegiatan, fasilitas, layanan, hingga koleksi yang dimilikinya. Promosi perpustakaan bertujuan untuk mengajak pemustaka agar lebih dekat dengan perpustakaan. Sehingga pemustaka tahu apa saja yang dapat dimanfaatkan dari sebuah perpustakaan. Terutama di masa pandemi seperti ini, perpustakaan harus melakukan sebuah langkah baru agar pemustaka tetap merasa terjangkau dan dekat dengan perpustakaan.

\section{PENUTUP}

\section{KESIMPULAN}

Masa pandemi COVID-19 yang terjadi di Indonesia sejak awal 2020 memberikan dampak yang sangat besar ke seluruh aspek kehidupan. Kebijakan-kebijakan untuk mencegah penyebaran wabah ini mulai gencar dilakukan, salah satunya ialah kebijakan PSBB. Pembatasan sosial ini juga berpengaruh terhadap perusahaan, lembaga, dan fasilitas umum 
ditutup sementara. Begitu pula dengan perpustakaan, baik perpustakaan nasional, perguran tinggi, dan perpustakaan daerah. Hal ini menjadi salah satu tantangan yang perlu dihadapi oleh perpustakaan. Perpustakaan Pusat melarang adanya kegiatan serta aktifitas di sekitar gedung perpustakaan. Untuk tetap dapat melayani pemustaka sebagaimana mestinya, Perpustakaan Pusat Unpad telah memanfaatkan beberapa website yang bisa diakses oleh pemustaka. Website tersebut berisi berbagai bahan pustaka digital dari berbagai publikasi serta disiplin ilmu. Pemustaka juga tetap dapat menggunakan berbagai macam jenis layanan yang diselenggarakan oleh Perpustakaan Pusat Unpad. Salah satu kegiatan layanan yang baru dibuka di saat masa pandemi COVID-19 ini ialah Layanan Pustakawan "Subject Specialist" di mana pemustaka dapat berkomunikasi dengan pustakawan sesuai disiplin ilmu seputar penelusuran bahan pustaka dan informasi lainnya. Inovasi ini menjadi sebuah jalan yang cerdas mengingat saat ini pemustaka tidak dapat mengunjungi perpustakaan dan berkomunikasi dengan pustakawan mengenai kebutuhan informasi secara tatap muka.

\section{SARAN}

Dari segi penyediaan koleksi digital, Perpustakaan Pusat Unpad telah menyediakan berbagai bahan pustaka dari berbagai disiplin ilmu yang dapat diakses oleh pemustaka. Koleksi digital ini menggunakan sistem SSO EzProxy yang memudahkan bagi pemustaka. Selain pengadaan koleksi, Perpustakaan Pusat Unpad juga melakukan kerjasama dengan berbagai pihak sebagai salah satu bentuk upaya untuk melengkapi koleksi yang telah dimiliki. Inovasi lain yang dilakukan oleh Perpustakaan Pusat Unpad agar tetap eksis di kalangan pemustakanya ialah dengan melakukan promosi melalui sosial media Instagram. Meskipun Inovasi ini baru saja dilakukan dan belum sesempurna perpustakaan perguran tinggi yang lain, ini menjadi salah satu inovasi yang baik dan dapat terus dikembangkan.

\section{DAFTAR PUSTAKA}

Aini, Q., Rahardja, U., \& Naufal, R. S. (2018). Penerapan Single Sign On dengan Google pada Webiste berbasis YII Framework. 8(1), 57-68.

Ananda, S., \& Nelisa, M. (2013). Hubungan Komunikasi Interpersonal Antara Pustakawan Dan Pemustaka Di Perpustakaan Smk Negeri 2 Padang. Jurnal

Ilmu Informasi Perpustakaan Dan Kearsipan, 2(1), 229-235.

Barlian, E. (2016). Metodologi Penelitian Kualitatif \& Kuantitatif(1st ed.). Padang: Penerbit Sukabina Press.

Berawi, I. (2012). Mengenal Lebih Dekat Perpustakaan Perguruan Tinggi. Jurnal Iqra', 06(0), 49-62.

Dana, T., Samosir, D. H., \& Widiyasa, I. M. (2008). Pengembangan Digital Library Perpustakaan Universitas Atmajaya Yogyakarta. Seminar Nasional Informatika, 260-263.

Kusnayat, A., Sumarni, N., Mansyur, A. S., Zaqiah, Q. Y., \& Bandung, U. T. (2020). Pengaruh Teknologi Pembelajaran Kuliah Online Di Era Covid-19 Dan Dampaknya Terhadap Mental Mahasiswa. EduTeach: Jurnal Edukasi Dan Teknologi Pembelajaran, 1(2), 
$153-165$.

Maksum, Buldansyah, D. L., \& Prawati, B. (2008). Aksesibilitas Informasi, Intensitas Komunikasi, Dan Efektivitas Layanan Informasi Digital. Jurnal Perpustakaan Pertanian, 17(20), 48-55.

Mutia, R. (2017). Kerjasama perpustakaan sebagai bentuk pengembangan koleksi. Universitas Islam Negeri Ar-Raniry. Rahman, S. R. (2020). Pembelajaran Online di Tengah Pandemi Covid-19. 02(02), 81-89.

Rahmat, P. S. (2009). Penelitian Kualitatif. Equilibrium, 5(9), 1-8.

Suharso, P., Arifiyana, I. P., \& Wasdiana, D. (2020). Layanan Perpustakaan Perguruan Tinggi dalam Menghadapi Pandemi Covid-19. 4(2), 271-286.

Supriyanto, W. (n.d.). Pengembangan sistem layanan perpustakaan digital.

Tjiptasari, F., \& Ridwan, M. M. (2017). Kebutuhan Informasi Mahasiswa Fakultas Ilmu Pendidikan Universitas Negeri Yogyakarta. Pustakaloka, 9(1), 57-66.

Yenianti, I. (2019). Promosi Perpustakaan Melalui Media Sosial. Journal of Library and Information Science, 3(23), 223-237.

Yusuf, S. A., \& Khasanah, U. (2009). Kajian Literatur dan Teori Sosial dalam Penelitian. 